\title{
Discriminative stimulus effects of inhaled 1,1,1-trichloroethane in mice: comparison to other hydrocarbon vapors and volatile anesthetics
}

\author{
Keith L. Shelton
}

Received: 31 May 2008 / Accepted: 13 October 2008 / Published online: 30 October 2008

(C) Springer-Verlag 2008

\begin{abstract}
Rationale Because the toxicity of many inhalants precludes evaluation in humans, drug discrimination, an animal model of subjective effects, can be used to gain insights on their poorly understood abuse-related effects.

Objectives The purpose of the present study was to train a prototypic inhalant that has known abuse liability, 1,1,1trichloroethane (TCE), as a discriminative stimulus in mice, and compare it to other classes of inhalants.

Materials and methods Eight B6SJLF1/J mice were trained to discriminate $10 \mathrm{~min}$ of exposure to $12,000 \mathrm{ppm}$ inhaled TCE vapor from air and seven mice were trained to discriminate 4,000 ppm TCE from air. Tests were then conducted to characterize the discriminative stimulus of TCE and to compare it to representative aromatic and chlorinated hydrocarbon vapors, volatile halogenated anesthetics as well as an odorant compound.

Results Only the 12,000 ppm TCE versus the air discrimination group exhibited sufficient discrimination accuracy for substitution testing. TCE vapor concentration- and exposure time-dependently substituted for the $12,000 \mathrm{ppm}$ TCE vapor training stimulus. Full substitution was produced by trichloroethylene, toluene, enflurane, and sevoflurane. Varying degrees of partial substitution were produced by the other volatile test compounds. The odorant, 2-butanol, did not produce any substitution for TCE.

Conclusions The discriminative stimulus effects of TCE are shared fully or partially by chlorinated and aromatic hydrocarbons as well as by halogenated volatile anesthetics. However, these compounds can be differentiated from TCE
\end{abstract}

\section{K. L. Shelton $(\square)$}

Department of Pharmacology and Toxicology, Virginia

Commonwealth University School of Medicine,

P.O. Box 980613, Richmond, VA 23298-0613, USA

e-mail: klshelto@vcu.edu both quantitatively and qualitatively. It appears that the degree of similarity is not solely a function of chemical classification but may also be dependent upon the neurochemical effects of the individual compounds.

Keywords Drug discrimination · 1,1,1-Trichloroethane . Inhalant $\cdot$ Mice $\cdot$ Solvents

\section{Introduction}

Many abused inhalants such as toluene, ethylbenzene, and xylene are volatile aromatic hydrocarbons used as solvents in household and industrial products like printing inks, paints, paint thinners, and glues. A second class of solvents includes the chlorinated hydrocarbons such as perchloroethylene (PERC) and trichloroethylene (TRI) which are used in the dry cleaning industry and as spot removers and 1,1,1-trichloroethane (TCE) which was once an ingredient in typewriter correction fluid among other uses. Other abused hydrocarbons such as gasoline are mixtures of primarily aliphatic hydrocarbons. While inhalants can easily be grouped according to their chemical classification, it is unclear what degree of relevance these broad chemical categories have in regard to their behavioral and by extension neurochemical effects, especially those related to abuse.

The neurochemical effects of inhalants are believed to be quite complex (Balster 1998; Bowen et al. 2006). In vitro studies have shown that inhalants can allosterically modulate many different ion channels including $\mathrm{GABA}_{\mathrm{A}}$, $\mathrm{N}$-methyl-D-aspartate (NMDA), glycine, potassium, and acetylcholine (Bale et al. 2002; Beckstead et al. 2000, 2001, 2002; Cruz et al. 1998, 2000; Del Re et al. 2006; Riegel and French 2002). A few in vitro experiments have 
compared inhalants from different chemical classes, showing that they can be differentiated from one another based on their effects on recombinant receptors (Beckstead et al. 2000, 2001; Ogata et al. 2006). While it is intriguing that these molecular techniques can make very fine distinctions between the cellular actions of inhalants, evidence that volatile chemicals from the same family differ in their effects at native receptors has not yet been produced (Bale et al. 2005).

Drug discrimination studies comparing inhalants are also very limited, being almost exclusively composed of crosstests of inhalants in animals trained to discriminate injected drugs from vehicle (Balster 1998). These studies have shown that toluene and TCE produce some degree of pentobarbital, PCP, ethanol, or diazepam-like discriminative stimulus effects (Bowen and Balster 1997; Bowen et al. 1999; Rees et al. 1985, 1987a, b). These cross-test data have been informative but are limited in that they only directly compared the discriminative stimulus effects of inhalants to those of the injected training drugs, not to the discriminative stimulus of other inhalants (Evans and Balster 1991). Aside from studies using inhalants in odor discrimination procedures, only three studies have trained an abused inhalant using typical drug discrimination methods. In two of these studies, injected toluene was trained as a discriminative stimulus (Knisely et al. 1990; Rees et al. 1987c). Those studies found that methohexital, oxazepam, and pentobarbital but not chlorpromazine or morphine produced toluene-like discriminative stimulus effects. Neither of these studies attempted to compare the discriminative stimulus of injected toluene to other inhalants. In a more recent study from our laboratory, we trained $6,000 \mathrm{ppm}$ toluene vapor as a discriminative stimulus (Shelton 2007). We found that a second aromatic hydrocarbon vapor, ethylbenzene, produced partial substitution for toluene whereas the halogenated ether anesthetic vapor, isoflurane, did not have toluene-like discriminative stimulus effects.

Although toluene is perhaps the best behaviorally characterized of the commonly abused inhalants (Bowen et al. 2006), it is closely followed in that regard by TCE (Bowen and Balster 1996, 1998a, b; Moser and Balster 1985, 1986; Moser et al. 1985; Wiley et al. 2002). Like toluene, numerous deaths have been associated with TCE abuse (Flanagan and Ives 1994; Guberan et al. 1976; King et al. 1985; Ramsey et al. 1989; Troutman 1988; Winek et al. 1997). Due to its ozone-depleting effects, the manufacture and use of TCE has largely been abandoned in the developed world but it remains the most well characterized of the chlorinated hydrocarbons in terms of its central nervous system (CNS) effects. As such, TCE remains an important research tool given that many other chlorinated hydrocarbons like PERC and TRI are still widely used and have also been linked to abuse and abuse-related deaths (Isenschmid et al. 1998; Jones and Singer 2008; King et al. 1985; Michaux and Delevay-Le Gueut 1980).

The goals of the present study were to train a discrimination based on TCE vapor and then compare the discriminative stimulus of TCE to representative inhalants from several chemical classes. We hypothesized that the discriminative stimulus effects of TCE might be shared by other chlorinated hydrocarbons, but dissimilar to those of inhalants from other chemical classes. We chose to train two different concentrations of TCE as discriminative stimuli. A $12,000 \mathrm{ppm}$ TCE concentration was chosen as the high concentration training stimulus since concentrations in this range have been reported to produce pronounced CNS-mediated behavioral effects (Bowen and Balster 1996, 1998a). We selected a concentration of 4,000 ppm TCE vapor as the low concentration training stimulus since this concentration is in the range reported to be just above the threshold for altering locomotor activity and rates of operant responding in mice (Bowen and Balster 1996, 1998a). It was our hypothesis that these two discrimination conditions might produce different substitution profiles much as has been shown with high and low ethanol training doses (Grant and Colombo 1993a, b; Grant 1999).

\section{Materials and methods}

Subjects

Fifteen adult male B6SJLF1/J mice (Jackson Laboratory, Bar Harbor, ME, USA) served as subjects. We have previously used this strain in our laboratory for drug discrimination studies with ethanol as well as toluene (Shelton 2007; Shelton et al. 2004). The mice were individually housed on a 12-h light/dark cycle (lights on at $7 \mathrm{AM}$ ). Feeding was adjusted to maintain a healthy, stable weight of between 25 and $31 \mathrm{~g}$ for the duration of the study. These studies were reviewed and approved by the Institutional Animal Care and Use Committee of Virginia Commonwealth University.

\section{Compounds}

Anhydrous-99.5\%, 1,1,1-trichloroethane (TCE) HPLC grade toluene, $99 \% o$-xylene, and 2-butanol were purchased from Sigma-Aldrich Chemicals (Milwaukee, WI, USA); 99+\% stabilized trichloroethylene (TRI) and 99\% tetrachloroethylene (PERC) were supplied by Fisher Scientific (Acros Organic, NJ, USA). Enflurane was obtained from Abbott Laboratories (North Chicago, IL, USA). Isoflurane and sevoflurane were purchased from Webster Veterinary Supply (Charlotte, NC, USA). 


\section{Apparatus}

Drug discrimination sessions were conducted in standard 2lever mouse operant conditioning chambers equipped with $0.01 \mathrm{ml}$ liquid dippers and housed in sound attenuating cubicles (Med-associates model ENV-307AW, St. Albans, VT, USA). A single 5-W incandescent houselight was located at the top center of the chamber rear wall. Drug discrimination schedule conditions and data recording were accomplished using a Med-associates interfacing and software (Med-Associates, St. Albans, VT, USA). The milk solution reinforcer consisted of $25 \%$ sugar, $25 \%$ nonfat powdered milk, and 50\% tap water (by volume).

The static vapor chambers and general procedures used to expose the mice to TCE vapor prior to drug discrimination testing have been previously described (Shelton 2007; Shelton and Balster 2004). Closed-loop recirculation of chamber atmosphere through a single wavelength IR spectrometer indicated that TCE vapor concentration in the chambers reached equilibrium in less than $1 \mathrm{~min}$ for all tested concentrations and did not decrease by more than $10 \%$ over the course of the 10 -min exposure period [see (Shelton 2007) for more details of this procedure].

\section{Discrimination training}

Daily 15-min training sessions were conducted 5 days per week (M-F). Both lever lights and the houselight were illuminated for the duration of the session. During initial lever-press training, there were no differential stimuli other than reinforcer presentations with which to associate the active lever. The mice were first reinforced for responding on only one of the two levers on a fixed ratio 1 response (FR1) schedule for several daily sessions. Upon completion of the FR requirement, the dipper cup was available for $3 \mathrm{~s}$. Responses occurring while the dipper was elevated did not count toward completion of the next ratio requirement. Responding on the inactive lever reset the FR requirement on the correct lever. Once the animals were reliably responding at FR1 on either lever, the operant session length was decreased to $5 \mathrm{~min}$ and discrimination training was initiated. During each 5-min TCE or air discrimination training session, the correct lever was determined by whether the subject received a 10-min exposure to TCE vapor or air immediately before the discrimination training session. For seven mice, the discrimination was between 4,000 ppm TCE vapor and air and for the remaining eight mice the discrimination was between 12,000 ppm TCE vapor and air. Training exposures were presented according to a double alternation schedule (i.e., two TCE vapor days followed by two air days). Over the course of 10 to 20 sessions, the response requirement was increased to FR12. These training conditions were in effect for the remainder of the study. Animals were determined to have acquired the TCE vapor versus air discrimination when the first FR was completed on the correct lever, prior to the completion of a FR on the incorrect lever, in eight out of ten consecutive training sessions. Additionally, the mice were required to emit greater than $80 \%$ of responses on the correct lever during all ten of these sessions.

\section{Substitution test procedure}

Following acquisition, substitution tests were conducted on Tuesday and Friday, providing that the mice continued to exhibit accurate stimulus control on the Monday, Wednesday, and Thursday training sessions. Test sessions were temporarily suspended if an animal did not emit the first FR on the correct lever and produce greater than $80 \%$ correctlever responding during all training sessions since the last test session. Substitution tests with all vapors were preceded by a 10 -min exposure to a single concentration of vapor with the exception of the TCE exposure-time experiment in which the animals were tested following 1, 3, 7 , and $10 \mathrm{~min}$ of $12,000 \mathrm{ppm}$ TCE exposure. Following exposure, each animal was immediately removed from the exposure chamber and placed into the operant conditioning chamber for a 5-min test session. On test days, both levers were active and completion of the FR requirement on either lever resulted in dipper presentation. Vapor concentrations were generally administered in an ascending order. Each condition was tested once without regard for the prior days training condition (TCE vapor or air). Prior to each concentration-effect curve, two control substitution test sessions were conducted, one with the training concentration of TCE vapor and the second with air. Control test sessions were also conducted on Tuesday and Friday. No other substitution tests were conducted on a control test day.

\section{Blood TCE level analysis}

The same eight mice trained to discriminate $12,000 \mathrm{ppm}$ TCE versus air were used to examine TCE blood levels following $0,1,3$, or $10 \mathrm{~min}$ of $12,000 \mathrm{ppm}$ TCE exposure. To yield an $n=4$ for each of the four TCE exposure durations, two blood samples were taken from each mouse with at least 2 weeks between each sample. TCE exposure conditions prior to blood sampling were identical to drug discrimination exposure conditions except that rather than being tested in the discrimination procedure each mouse was briefly restrained and approximately $0.1 \mathrm{ml}$ of blood was obtained from the submandibular vascular bundle using a 5-mm lancet (Golde et al. 2005). Blood was captured in a microcollection tube containing EDTA (BD lavender top Microtainer). A $20-\mu 1$ blood sample was placed into a 20-ml headspace vial to which $980 \mu \mathrm{l}$ of 
type 1 ultrapure water had been previously added. The blood sample was then immediately tested for TCE concentration using a Hewlett Packard model 5890A gas chromatograph equipped with a flame ionization detector, a 2-m 5\% Carbowax 20M 80/120 mesh packed column (Restek, Bellefonte, PA, USA), and CTC Combi-Pal headspace autosampler.

Data analysis

Since the behavioral effects of some of the tested inhalants were expected to dissipate rapidly, potentially resulting in switching of responding between levers, only the choice of the lever upon which the first fixed ratio was completed was used to assess TCE-like discriminative stimulus effect. Response rates during the first minute of each test session were used to assess the inhalants effects on operant performance. Group means $( \pm \mathrm{SEM})$ were calculated for first fixed ratio responding as well as response rate. Any vapor concentration that suppressed response rates to the extent that the animal did not complete at least 1 FR during the first minute of the test session resulted in the exclusion of that mouse's datum point from the group lever selection analysis, although that animal's datum point was included in the response rate determination. A criterion of $80 \%$ or greater mean TCE vapor-appropriate responding was selected to indicate full substitution for the training concentration of TCE vapor. Mean TCE vapor-lever responding between $20 \%$ and $79 \%$ was defined as partial substitution. Mean TCE vapor-lever responding of less than $20 \%$ was considered evidence of no substitution. When possible, $\mathrm{EC}_{50}$ values (and 95\% confidence limits) for TCE vapor-lever selection and response rate suppression were calculated based on the linear portion of each mean doseeffect curve using a Microsoft Excel spreadsheet based on SAS Pharm/PCS version 4 (Tallarida and Murray 1986). $\mathrm{EC}_{50}$ values for individual concentration effect curves were considered significantly different from each other when their respective $95 \%$ confidence limits did not overlap.

\section{Results}

The mice trained to discriminate $12,000 \mathrm{ppm}$ TCE versus air rapidly acquired the discrimination, requiring a mean of $27( \pm 1.8)$ sessions at FR12 to reach the acquisition criteria. Despite up to 116 training sessions, only three of seven mice in the 4,000-ppm TCE discrimination reached acquisition criteria, and these animals did not exhibit sufficient reliability to permit substitution testing. Based on these data, training of the $4,000 \mathrm{ppm}$ TCE versus air group was terminated and subsequent substitution results are from only the $12,000 \mathrm{ppm}$ TCE training group.
TCE vapor concentration-dependently substituted for the 12,000 ppm TCE vapor training concentration (Fig. 1, upper panel) with an $\mathrm{EC}_{50}$ value of 2,887 ppm (CL 2,0514,064 ppm). The control tests following $10 \mathrm{~min}$ of exposure to air and $12,000 \mathrm{ppm}$ TCE produced $0 \%$ and $100 \%$ TCElever responding, respectively. TCE vapor produced concentration-dependent suppression of operant responding (Fig. 1, lower panel) with an $\mathrm{EC}_{50}$ of $19,998 \mathrm{ppm}$ (CL 17,824-22,437 ppm).

Exposure to $12,000 \mathrm{ppm}$ TCE vapor time-dependently substituted for the 10-min training exposure (Fig. 2). Exposure to 12,000 ppm of TCE vapor for 1 min produced $37 \%$ TCE-lever responding and a mean TCE blood concentration of $109( \pm 7) \mu \mathrm{g} / \mathrm{ml}$. Three minutes of $12,000 \mathrm{ppm}$ TCE vapor exposure resulted in $62 \%$ TCE-
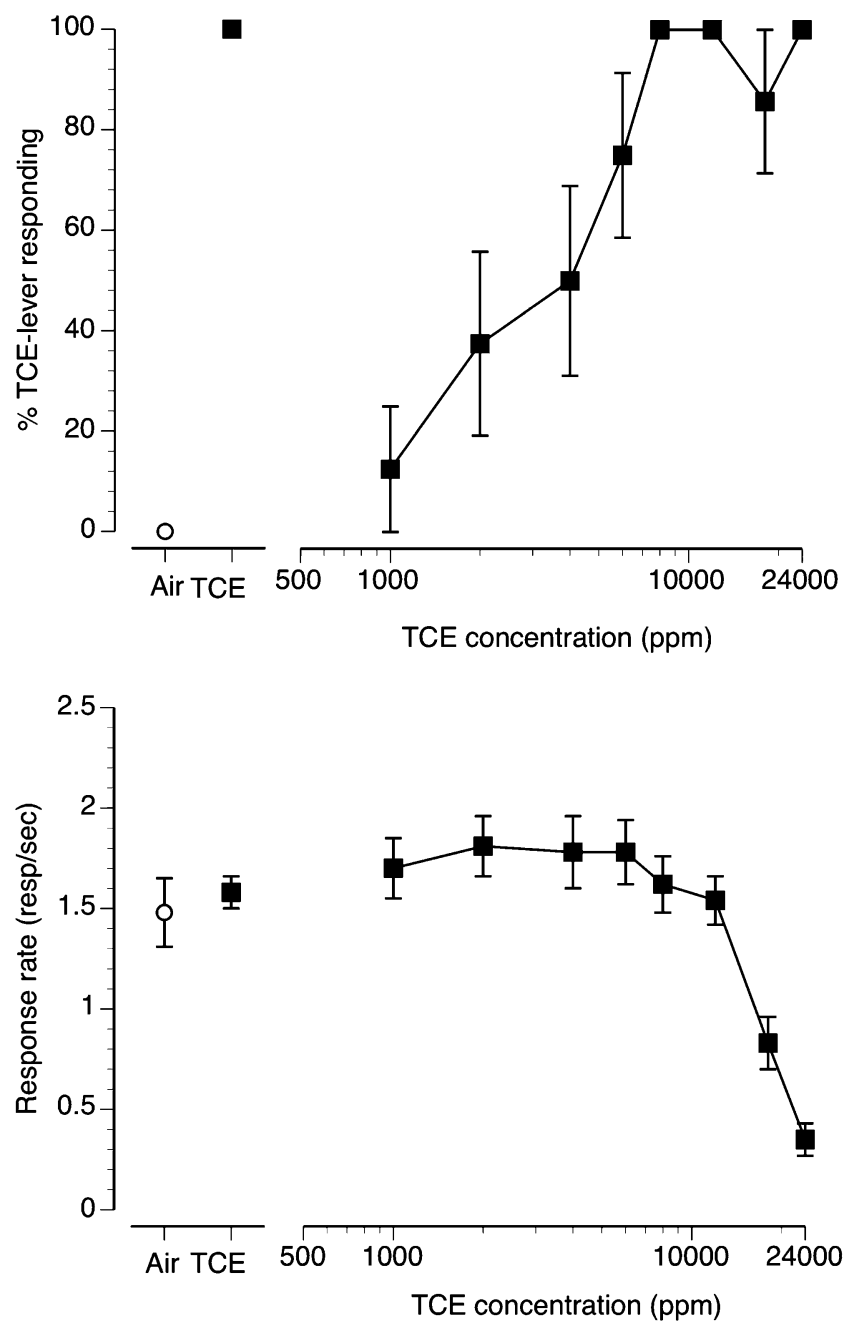

Fig. 1 Concentration-effect curve for inhaled 1,1,1-trichloroethane (TCE) vapor in eight mice trained to discriminate $12,000 \mathrm{ppm}$ inhaled TCE from air. Mean $( \pm$ SEM) percentages TCE-lever responding is shown in the upper panel (filled squares/solid line). Mean $( \pm \mathrm{SEM})$ response rates in responses per second during each test session are shown in the bottom panel. Open circle above air and filled square above TCE represent the results of the control test sessions 


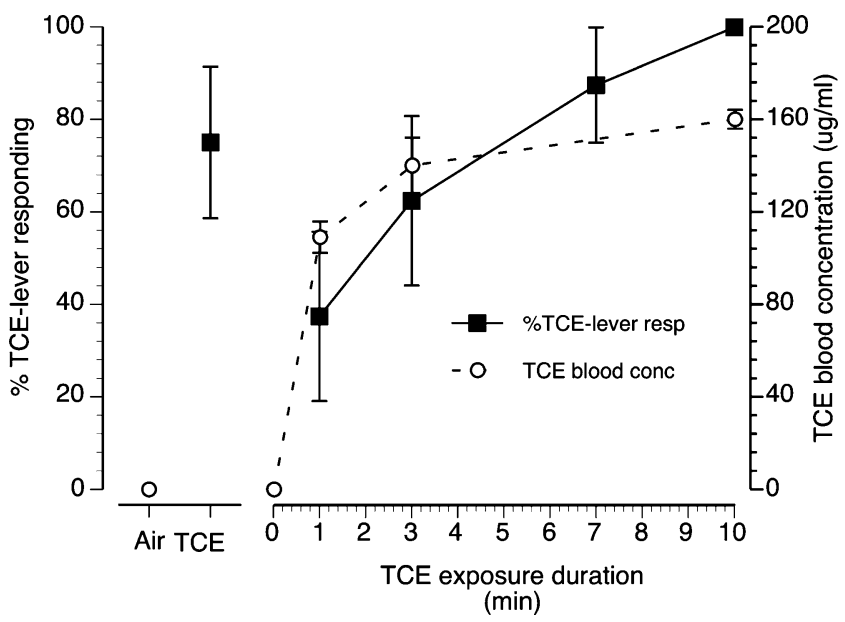

Fig. 2 Mean percentage TCE-lever responding and TCE blood levels for eight mice exposed for increasing durations to $12,000 \mathrm{ppm}$ inhaled TCE vapor. Mean ( \pm SEM) percentage TCE-lever responding is shown by the filled squares and solid line. TCE blood level in microgram per milliliter is shown by open circles and dashed line. Open circle above air and filled square above TCE represent percentage TCE-lever responding during control test sessions which were preceded by $10 \mathrm{~min}$ of air or $12,000 \mathrm{ppm}$ TCE vapor exposure, respectively

lever selection and a mean TCE blood concentration of 140 $( \pm 12) \mu \mathrm{g} / \mathrm{ml}$. Ten minutes of exposure to $12,000 \mathrm{ppm}$ TCE vapor produced $100 \%$ TCE-lever responding and a mean TCE blood concentration of $160( \pm 4) \mu \mathrm{g} / \mathrm{ml}$.

TCE, PERC, and TRI all produced concentrationdependent increases in TCE-lever selection (Fig. 3, upper panel). TCE fully substituted for the $12,000 \mathrm{ppm}$ training condition with an $\mathrm{EC}_{50}$ of 4,036 ppm (CL 3,329$4,894 \mathrm{ppm})$. TRI also fully substituted for TCE vapor with an $\mathrm{EC}_{50}$ of 4,031 ppm (CL 3,012-5,395 ppm). In contrast, PERC did not fully substitute for TCE, producing an $\mathrm{EC}_{50}$ for substitution of 1,277 ppm (CL 896-1,820 ppm) which was significantly lower than the $\mathrm{EC}_{50}$ for either TCE or TRI. TCE showed little effect on rates of operant responding but both TRI and PERC produced concentrationdependent reductions in rates of operant responding (Fig. 3, lower panel). The $\mathrm{EC}_{50}$ 's for rate suppression were 5,621 ppm (CL 5,005-6,313 ppm) and 2,434 ppm (CL 2,084-2,841 ppm) for TRI and PERC, respectively.

The three aromatic hydrocarbons; toluene, ethylbenzene, and $o$-xylene, produced varying degrees of substitution for TCE (Fig. 4, upper panel). Toluene fully substituted for TCE vapor with an $\mathrm{EC}_{50}$ of 2,632 ppm (CL 1,963-3,529 ppm). Both ethylbenzene and $o$-xylene produced concentrationdependent partial substitution for TCE vapor. The $\mathrm{EC}_{50}$ for $o$-xylene vapor substitution for TCE was $3,530 \mathrm{ppm}$ (CL 1,883-6,617 ppm). Toluene and ethylbenzene had less pronounced rate suppressing effects than $o$-xylene, which concentration-dependently suppressed operant responding with an $\mathrm{EC}_{50}$ of 7,080 ppm (CL 5,064-9,898 ppm).
All three halogenated hydrocarbon anesthetic vapors produced dose-dependent substitution for the 12,000 ppm TCE training concentration (Fig. 5, upper panel). Enflurane and sevoflurane fully and isoflurane partially substituted for TCE. The $\mathrm{EC}_{50}$ 's for enflurane and sevoflurane substitution were 4,387 ppm (CL 2,883-6,676 ppm) and 7,663 ppm (CL 6,308-9,309 ppm), respectively. None of the three volatile anesthetics produced pronounced response-rate suppressing effects at the tested concentrations with the exception of 18,000 ppm sevoflurane (Fig. 5, lower panel). The $\mathrm{EC}_{50}$ for response rate suppression by sevoflurane was $15,887 \mathrm{ppm}$ (CL 12,904-19,560 ppm). None of the tested concentrations of 2-butanol produced any TCE-lever selection in any of the mice tested (Table 1). Concurrent exposure to $30 \mathrm{ppm}$, 2-butanol also had no effect on the
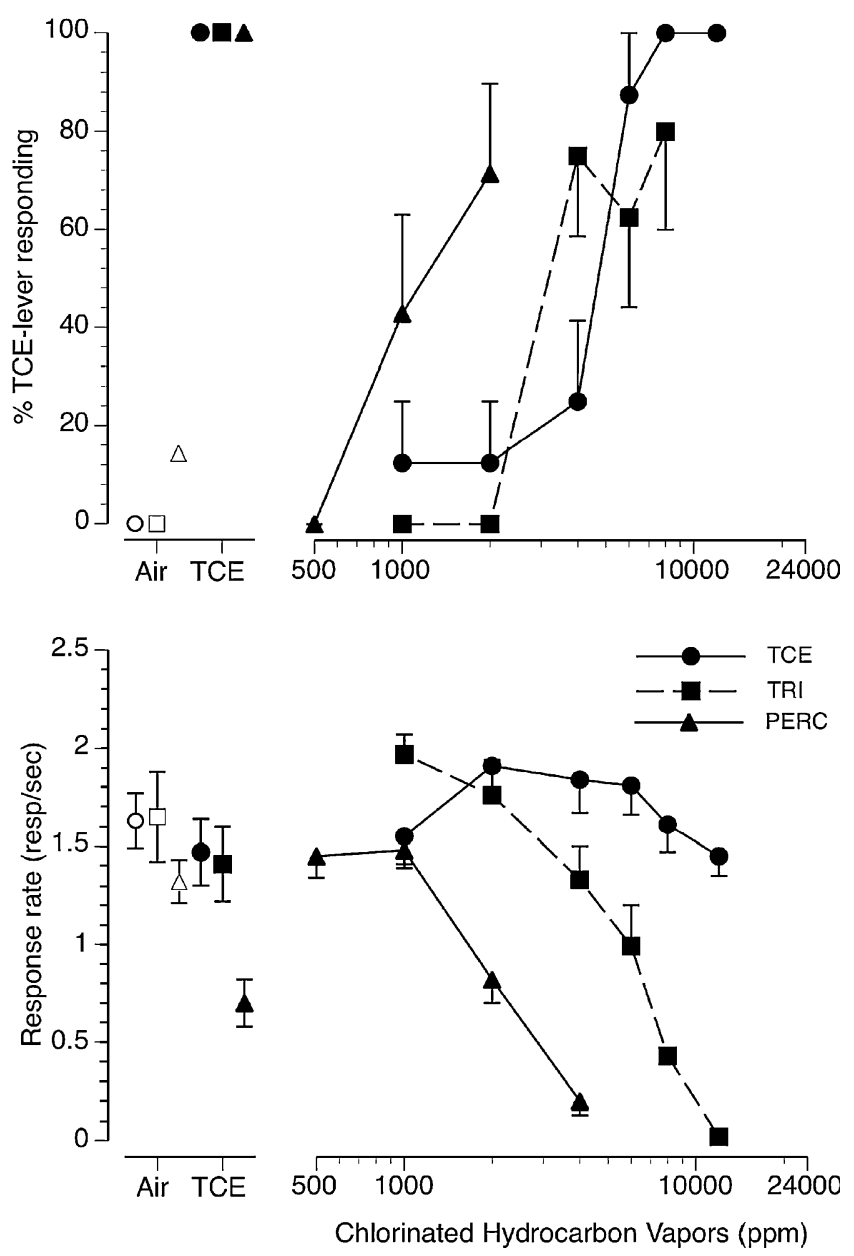

Fig. 3 Concentration-effect curves for inhaled TCE, trichloroethylene (TRI), and perchloroethylene (PERC) in mice trained to discriminate $12,000 \mathrm{ppm}$ inhaled TCE from air. Mean $( \pm$ SEM) percentage TCElever responding for TCE (filled circles/solid line), TRI (filled squares/dashed line) and PERC (filled triangles/solid line) are shown in the upper panel. Mean $( \pm \mathrm{SEM})$ response rates in responses per second are shown in the bottom panel. Open symbols above air represent the results of air exposure control sessions. Filled symbols above TCE represent the results of $12,000 \mathrm{ppm}$ TCE exposure control sessions 

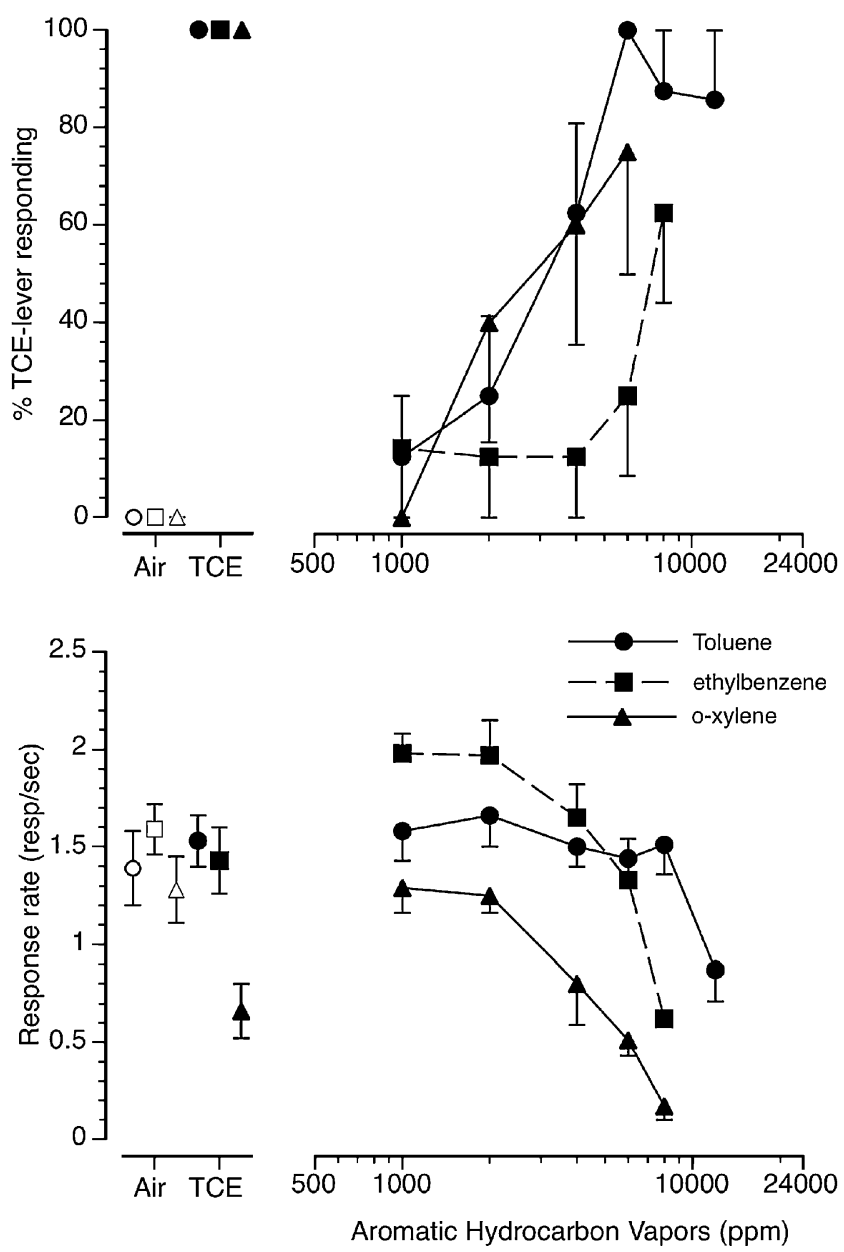

Fig. 4 Concentration-effect curves for inhaled toluene, ethylbenzene, and $o$-xylene in mice trained to discriminate $12,000 \mathrm{ppm}$ inhaled TCE from air. Mean $( \pm$ SEM) percentage TCE-lever responding for toluene (filled circles/solid line), ethylbenzene (filled squares/dashed line), and $o$-xylene (filled triangles/solid line) are shown in the upper panel. Mean $( \pm \mathrm{SEM})$ response rates in responses per second are shown in the bottom panel. Open symbols above air represent the results of air exposure control sessions. Filled symbols above TCE represent the results of 12,000 ppm TCE exposure control sessions

ability of $10 \mathrm{~min}$ of exposure to $12,000 \mathrm{ppm}$ TCE to produce full substitution.

\section{Discussion}

Most, if not all volatile compounds, have odor thresholds well below concentrations at which they produce CNS effects. For this reason, tests designed to assess the relative importance of olfactory cues versus CNS effects as controlling variables over discriminative stimulus performance are important. In our prior experiment using $10 \mathrm{~min}$ of exposure to $6,000 \mathrm{ppm}$ toluene vapor as a discriminative stimulus, we demonstrated that 1 and $3 \mathrm{~min}$ of $6,000 \mathrm{ppm}$ toluene exposure did not substitute for the 10-min training exposure (Shelton 2007). This finding, as well as other control tests demonstrating that injected liquid toluene substituted for inhaled toluene, strongly suggested that the discriminative stimulus of toluene in that experiment was mediated by CNS mechanisms. In the present study the extremely rapid absorption kinetics of TCE made it uncertain if we could conduct a similar exposure duration experiment to assess the importance of olfactory versus CNS cues. Significant TCE blood levels in humans have been detected with as little as $10 \mathrm{~s}$ of TCE vapor exposure (Astrand 1975) and blood pressure changes were observed in dogs after only $15 \mathrm{~s}$ of exposure (Herd et al. 1974). Indeed, our TCE blood concentration data confirm the rapid uptake of TCE in mice (Warren et al. 2000) with 1 min of exposure producing $68 \%$ of the level associated with
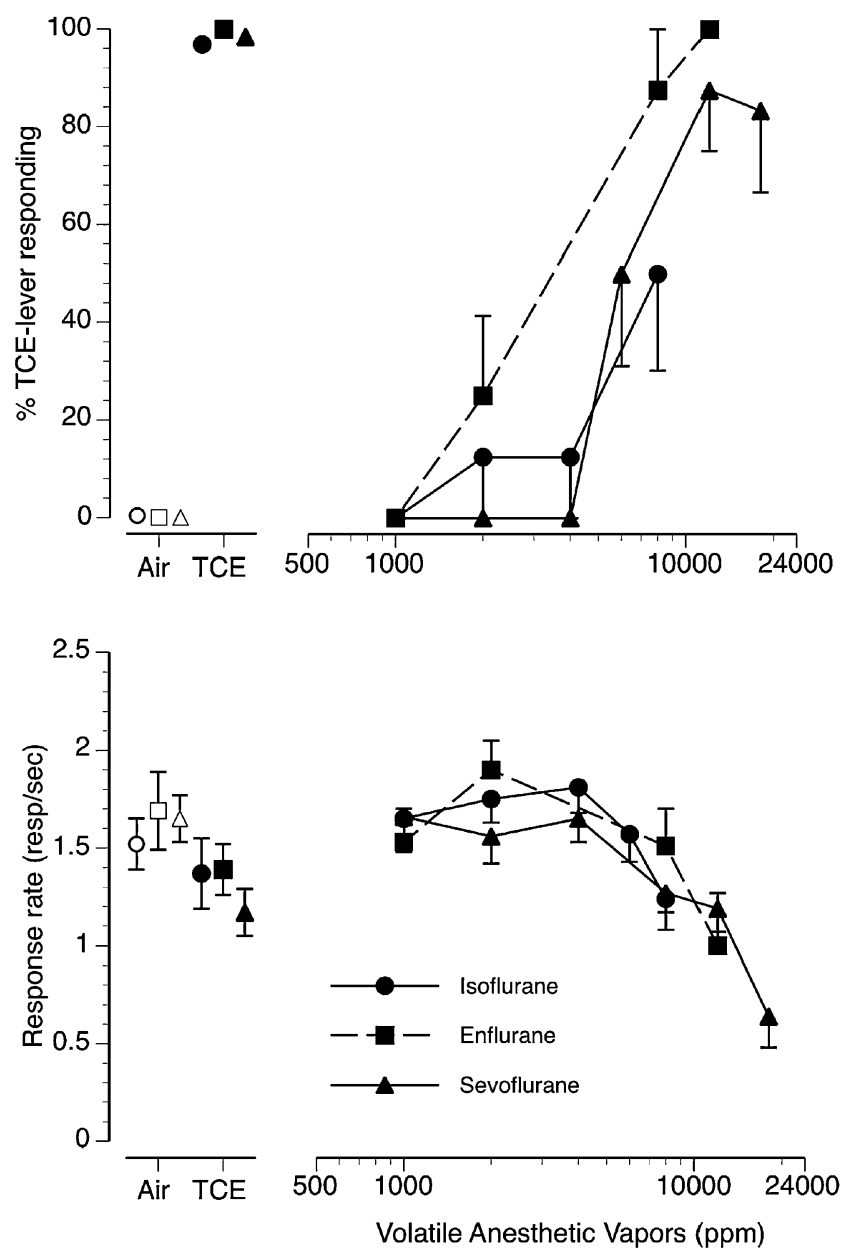

Fig. 5 Concentration-effect curves for inhaled isoflurane, enflurane, and sevoflurane in mice trained to discriminate $12,000 \mathrm{ppm}$ inhaled TCE from air. Mean $( \pm$ SEM) percentage TCE-lever responding for isoflurane (filled circles/solid line), enflurane (filled squares/dashed line), and sevoflurane (filled triangles/solid line) are shown in the upper panel. Mean $( \pm \mathrm{SEM})$ response rates in responses per second are shown in the bottom panel. Open symbols above air represent the results of air exposure control sessions. Filled symbols above TCE represent the results of $12,000 \mathrm{ppm}$ TCE exposure control sessions 
Table 1 1,1,1-trichloroethane (TCE) lever responding following $10 \mathrm{~min}$ of exposure to 2-butanol vapor

\begin{tabular}{lc}
\hline 2-Butanol concentration & $\begin{array}{l}\text { \% TCE-lever } \\
\text { responding }( \pm S E M)\end{array}$ \\
\hline Air control & $0(0)$ \\
12,000 ppm TCE control & $100(0)$ \\
12,000 ppm TCE +30 ppm 2-butanol & $100(0)$ \\
1 ppm 2-butanol & $0(0)$ \\
10 ppm 2-butanol & $0(0)$ \\
30 ppm 2-butanol & $0(0)$ \\
100 ppm 2-butanol & $0(0)$
\end{tabular}

10 min of exposure. Despite this rapid uptake, the exposure time-effect curve showed that it required at least $7 \mathrm{~min}$ of $12,000 \mathrm{ppm}$ TCE exposure to fully substitute for the 10min training exposure. If odor alone were sufficient to produce the discriminative stimulus effect of TCE, then one might expect much shorter exposures to have yielded full substitution.

Our results showing that $10 \mathrm{~min}$ of exposure to a low concentration of TCE failed to produce a reliable discrimination is probably not surprising if odor was not controlling behavior. It is also possible that the mice simply could not detect the odor of 4,000 ppm TCE whereas $12,000 \mathrm{ppm}$ TCE was above their odor threshold and therefore discriminable. The olfactory threshold for TCE has not been assessed in mice, so this hypothesis cannot be completely discounted. However, the odor threshold for TCE in humans has been reported to be as low as 100140 ppm (Amoore and Hautala 1983; Torkelson and Rowe 1981) and humans report that 350-450 ppm TCE causes dizziness, excitation, and eye irritation (Salvini et al. 1971). Mice have over three times the number of functional olfactory receptor genes compared to humans and are generally assumed to have equal or greater olfactory ability (Young et al. 2002). The low training concentration of $4,000 \mathrm{ppm}$ TCE was far in excess of the odor threshold in humans suggesting the odor was likely detectable by the mice, providing additional circumstantial evidence that the olfactory effects of TCE probably played at best a minor role in its discriminative stimulus under the present training conditions.

With one exception, all of the compounds tested produced at least partial substitution for TCE. The two possible interpretations of these data are that each of the compounds act at least to some degree via common CNS receptor mechanisms or any strong odor is sufficient to produce TCE-lever responding. Support for the latter interpretation is diminished not only by the data discussed above but also from the results of tests with the secondary alcohol, 2-butanol. Concentrations of 2-butanol up to 100 times that used in a prior olfactory discrimination study in mice (Laska and Shepherd 2007) failed to produce any substitution for 12,000 ppm TCE, nor did the concurrent exposure of the mice to $30 \mathrm{ppm}$ 2-butanol along with $12,000 \mathrm{ppm}$ TCE effect the ability of the training concentration of TCE to produce full substitution (Table 1). One additional test which might be conducted to further examine if olfactory mechanisms are involved in the discrimination would be to perform substitution testing in mice with chemically induced anosmia. However, even this experiment would not be sufficient to conclusively prove that the discrimination was based on CNS mechanisms, given that chemical-induced anosmia does not affect the trigeminal odor detection system which is almost certainly activated at the high concentrations of inhalants used in the present experiment (Cometto-Muniz et al. 2001, 2002).

If one accepts the preponderance of data indicating that the discriminative stimulus effects of TCE were likely CNS-mediated, two major questions arise. Firstly, what neurotransmitter receptor system or systems are responsible for transducing the discriminative stimulus of TCE. Although the available data are extremely limited, several ligand-gated ion channel receptor systems have been implicated in the neurochemical effects of TCE. TCE is a positive allosteric modulator of $\mathrm{GABA}_{\mathrm{A}}$ receptors expressed in Xenopus oocytes (Beckstead et al. 2000). TCE also potently inhibits NMDA-induced currents (Cruz et al. 2000) and PERC inhibits nicotinic acetylcholine receptors in oocytes (Bale et al. 2005). Finally, TCE enhances the function of recombinant $5-\mathrm{HT}_{3}$ receptors (Lopreato et al. 2003). Whether any or all of these neurotransmitter systems are involved in mediating the discriminative stimulus effects of TCE is a difficult question to address from the present data. However, as previously noted, TCE partially substitutes in mice trained to discriminate diazepam (Bowen et al. 1999), pentobarbital (Rees et al. 1987a), or ethanol (Rees et al. 1987b) from vehicle, supporting the hypothesis that the discriminative stimulus effects of TCE result from positive allosteric modulation of $\mathrm{GABA}_{\mathrm{A}}$ receptors. This hypothesis is strengthened by the present data showing full substitution of enflurane and sevoflurane for TCE. Both of these volatile anesthetic compounds have been shown to act as positive modulators of GABAergic receptors using in vitro procedures (Jia et al. 2008; Kelly et al. 2007; Nishikawa and Harrison 2003).

In contrast, TCE does not substitute in mice trained to discriminate the noncompetitive NMDA receptor channel blockers, dizocilpine (MK-801) or phencyclidine from saline (Bowen et al. 1999; Shelton and Balster 2004). These findings argue against a NMDA-receptor-mediated discriminative stimulus, even though TCE has been shown to inhibit NMDA-induced currents in oocytes (Cruz et al. 2000). Unfortunately, the predictive utility of cross-test data 
for assessing the mechanism of action of a drug with multiple targets may be seriously limited by the phenomena of asymmetrical substitution (Kostowski and Bienkowski 1999). As an example, drug discrimination studies have consistently shown that positive $\mathrm{GABA}_{\mathrm{A}}$ modulators, NMDA antagonists, and some subtype-specific 5-HT agonists will fully substitute in ethanol-trained animals [for review see (Grant 1999)]. However, when ethanol is tested for substitution in animals that are trained to discriminate these classes of compounds from vehicle, it often produces little or no substitution (Balster et al. 1992; Butelman et al. 1993; York 1978). Since all of the available drug discrimination data with TCE, aside from that in the present study, are from similar cross-test experiments, it is still premature to rule out NMDA receptor mechanisms playing a role in transducing TCE's discriminative stimulus.

The second major question which arises from the present data is whether the discriminative stimulus of all of the inhalants tested are mediated by identical, overlapping, or completely distinct receptor mechanisms. Our present data suggests that the discriminative stimulus of these compounds is at the very least not identical. For instance, TRI and PERC are both chlorinated hydrocarbons like TCE but were not capable of producing the same level of substitution as TCE itself. In contrast, toluene and enflurane produced full substitution for TCE in every mouse tested while the other compounds examined from these chemical groups did not substitute as robustly. A prior experiment from our laboratory using toluene vapor as a discriminative stimulus strengthens the hypothesis that all inhalants are not functionally equivalent (Shelton 2007). In that experiment, we found that ethylbenzene vapor produced partial substitution for toluene vapor, but that isoflurane had no toluenelike discriminative stimulus effects. Whereas in the present study, toluene produced full substitution while ethylbenzene and isoflurane only produced partial substitution for TCE vapor.

A few experiments in humans have directly compared the subjective effects of inhalants using self-report questionnaires. Due to the toxicity of many inhalants, these clinical studies have been by necessity limited to comparing between volatile and gas anesthetics, but they are nonetheless informative. For instance, it has been shown that the subjective ratings produced by nitrous oxide differ from those of isoflurane (Zacny et al. 1994) and sevoflurane (Zacny et al. 1999) but that isoflurane and sevoflurane were indistinguishable from each other (Beckman et al. 2006). The authors suggested that the ability to differentiate between nitrous oxide and the volatile anesthetics was due to nitrous oxide producing NMDA antagonist effects that were not present in the volatile anesthetic vapors. This hypothesis is strengthened by in vitro data showing that isoflurane strongly enhances $\mathrm{GABA}_{\mathrm{A}}$ receptor currents but is a weak inhibitor of NMDA receptor currents in Xenopus oocytes (Kelly et al. 2007). While we did not test nitrous oxide, our results are consistent with the human studies in as much as all three volatile anesthetics we tested produced at least partial substitution for TCE.

It is certainly possible that the differing effects of the volatile compounds in the present study were due to variability inherent in the drug discrimination procedure or the interfering effects of response rate suppression. However, there are some data from studies examining ion channel receptors expressed in Xenopus oocytes suggesting that our results may be due to selective difference in actions of these volatile compounds at the neurotransmitter receptor level. For instance, in the present study, the volatile anesthetic vapor enflurane produced full substitution for TCE while the more closely chemically related compound, PERC, only partially substituted for TCE. In a parallel finding, glycine receptors expressed in Xenopus oocytes show a high degree of correlation between those mutations which affected both enflurane and TCE enhancement of glycine receptor function (Beckstead et al. 2000), and several mutations were also noted which affected glycine receptor sensitivity to toluene and TRI, but not TCE. Another experiment in recombinant $\mathrm{GABA}_{\mathrm{A}}$ receptors demonstrated that a mutation of S265I resulted in $\mathrm{GABA}_{\mathrm{A}}$ receptors which were sensitive to potentiation by both enflurane and TRI but not by isoflurane (Krasowski and Harrison 2000). These latter data are consistent with our findings that both TRI and enflurane produced full substitution for TCE but that isoflurane only partially substituted for TCE.

Taken as a whole, the present results support the conclusion that the discriminative stimuli of inhalants are not identical. They also suggest that the substitution of a particular test compound cannot be entirely predicted by chemical classification. Lastly, the present findings underscore the importance of examining a variety of different inhalants using in vivo procedures such as drug discrimination in order to better understand their unique pharmacological effects.

\section{References}

Amoore JE, Hautala E (1983) Odor as an aid to chemical safety: odor thresholds compared with threshold limit values and volatilities for 214 industrial chemicals in air and water dilution. J Appl Toxicol 3:272-290

Astrand I (1975) Uptake of solvents in the blood and tissues of man. A review. Scand J Work Environ Health 1:199-218

Bale AS, Smothers CT, Woodward JJ (2002) Inhibition of neuronal nicotinic acetylcholine receptors by the abused solvent, toluene. Br J Pharmacol 137:375-383

Bale AS, Tu Y, Carpenter-Hyland EP, Chandler LJ, Woodward JJ (2005) Alterations in glutamatergic and gabaergic ion channel 
activity in hippocampal neurons following exposure to the abused inhalant toluene. Neuroscience 130:197-206

Balster RL (1998) Neural basis of inhalant abuse. Drug Alcohol Depend 51:207-214

Balster RL, Grech DM, Bobelis DJ (1992) Drug discrimination analysis of ethanol as an $\mathrm{N}$-methyl-D-aspartate receptor antagonist. Eur J Pharmacol 222:39-42

Beckman NJ, Zacny JP, Walker DJ (2006) Within-subject comparison of the subjective and psychomotor effects of a gaseous anesthetic and two volatile anesthetics in healthy volunteers. Drug Alcohol Depend 81:89-95

Beckstead MJ, Weiner JL, Eger EI 2nd, Gong DH, Mihic SJ (2000) Glycine and gamma-aminobutyric acid(A) receptor function is enhanced by inhaled drugs of abuse. Mol Pharmacol 57:1199-1205

Beckstead MJ, Phelan R, Mihic SJ (2001) Antagonism of inhalant and volatile anesthetic enhancement of glycine receptor function. J Biol Chem 276:24959-24964

Beckstead MJ, Phelan R, Trudell JR, Bianchini MJ, Mihic SJ (2002) Anesthetic and ethanol effects on spontaneously opening glycine receptor channels. J Neurochem 82:1343-1351

Bowen SE, Balster RL (1996) Effects of inhaled 1,1,1-trichloroethane on locomotor activity in mice. Neurotoxicol Teratol 18:77-81

Bowen SE, Balster RL (1997) Desflurane, enflurane, isoflurane and ether produce ethanol-like discriminative stimulus effects in mice. Pharmacol Biochem Behav 57:191-198

Bowen SE, Balster RL (1998a) A direct comparison of inhalant effects on locomotor activity and schedule-controlled behavior in mice. Exp Clin Psychopharmacol 6:235-247

Bowen SE, Balster RL (1998b) The effects of inhaled isoparaffins on locomotor activity and operant performance in mice. Pharmacol Biochem Behav 61:271-280

Bowen SE, Wiley JL, Jones HE, Balster RL (1999) Phencyclidineand diazepam-like discriminative stimulus effects of inhalants in mice. Exp Clin Psychopharmacol 7:28-37

Bowen SE, Batis JC, Paez-Martinez N, Cruz SL (2006) The last decade of solvent research in animal models of abuse: mechanistic and behavioral studies. Neurotoxicol Teratol 28:636-647

Butelman ER, Baron SP, Woods JH (1993) Ethanol effects in pigeons trained to discriminate MK 801, PCP or CGS-19755. Behav Pharmacol 4:57-60

Cometto-Muniz JE, Cain WS, Abraham MH, Gola JM (2001) Ocular and nasal trigeminal detection of butyl acetate and toluene presented singly and in mixtures. Toxicol Sci 63:233-244

Cometto-Muniz JE, Cain WS, Abraham MH, Gola JM (2002) Psychometric functions for the olfactory and trigeminal detectability of butyl acetate and toluene. J Appl Toxicol 22:25-30

Cruz SL, Mirshahi T, Thomas B, Balster RL, Woodward JJ (1998) Effects of the abused solvent toluene on recombinant $N$-methylD-aspartate and non- $N$-methyl-D-aspartate receptors expressed in Xenopus oocytes. J Pharmacol Exp Ther 286:334-340

Cruz SL, Balster RL, Woodward JJ (2000) Effects of volatile solvents on recombinant $N$-methyl-D-aspartate receptors expressed in Xenopus oocytes. Br J Pharmacol 131:1303-1308

Del Re AM, Dopico AM, Woodward JJ (2006) Effects of the abused inhalant toluene on ethanol-sensitive potassium channels expressed in oocytes. Brain Res 1087:75-82

Evans EB, Balster RL (1991) CNS depressant effects of volatile organic solvents. Neurosci Biobehav Rev 15:233-241

Flanagan RJ, Ives RJ (1994) Volatile substance abuse. Bull Narc 46:49-78

Golde WT, Gollobin P, Rodriguez LL (2005) A rapid, simple, and humane method for submandibular bleeding of mice using a lancet. Lab Anim (NY) 34:39-43

Grant KA (1999) Strategies for understanding the pharmacological effects of ethanol with drug discrimination procedures. Pharmacol Biochem Behav 64:261-267
Grant KA, Colombo G (1993a) Discriminative stimulus effects of ethanol: effect of training dose on the substitution of $N$-methyl-Daspartate antagonists. J Pharmacol Exp Ther 264:1241-1247

Grant KA, Colombo G (1993b) Pharmacological analysis of the mixed discriminative stimulus effects of ethanol. Alcohol Alcohol Suppl 2:445-449

Guberan E, Fryc O, Robert M (1976) Sudden death from ventricular fibrillation after voluntary inhalation of chlorothene in a mechanics apprentice. Schweiz Med Wochenschr 106:119-121

Herd PA, Lipsky M, Martin HF (1974) Cardiovascular effects of 1,1,1-trichloroethane. Arch Environ Health 28:227-233

Isenschmid DS, Cassin BJ, Hepler BR, Kanluen S (1998) Tetrachloroethylene intoxication in an autoerotic fatality. J Forensic Sci 43:231-234

Jia F, Yue M, Chandra D, Homanics GE, Goldstein PA, Harrison NL (2008) Isoflurane is a potent modulator of extrasynaptic GABA(A) receptors in the thalamus. J Pharmacol Exp Ther 324:1127-1135

Jones GR, Singer PP (2008) An unusual trichloroethanol fatality attributed to sniffing trichloroethylene. J Anal Toxicol 32:183-186

Kelly EW, Solt K, Raines DE (2007) Volatile aromatic anesthetics variably impact human gamma-aminobutyric acid type A receptor function. Anesth Analg 105:1287-1292

King GS, Smialek JE, Troutman WG (1985) Sudden death in adolescents resulting from the inhalation of typewriter correction fluid. JAMA 253:1604-1606

Knisely JS, Rees DC, Balster RL (1990) Discriminative stimulus properties of toluene in the rat. Neurotoxicol Teratol 12:129-133

Kostowski W, Bienkowski P (1999) Discriminative stimulus effects of ethanol: neuropharmacological characterization. Alcohol 17:63-80

Krasowski MD, Harrison NL (2000) The actions of ether, alcohol and alkane general anaesthetics on GABAA and glycine receptors and the effects of TM2 and TM3 mutations. Br J Pharmacol 129:731-743

Laska M, Shepherd GM (2007) Olfactory discrimination ability of CD-1 mice for a large array of enantiomers. Neuroscience 144:295-301

Lopreato GF, Phelan R, Borghese CM, Beckstead MJ, Mihic SJ (2003) Inhaled drugs of abuse enhance serotonin-3 receptor function. Drug Alcohol Depend 70:11-15

Michaux P, Delevay-Le Gueut M (1980) 3 cases of death in trichloroethylene addicts. Acta Med Leg Soc (Liege) 30:89-94

Moser VC, Balster RL (1985) Acute motor and lethal effects of inhaled toluene, 1,1,1-trichloroethane, halothane, and ethanol in mice: effects of exposure duration. Toxicol Appl Pharmacol 77:285-291

Moser VC, Balster RL (1986) The effects of inhaled toluene, halothane, 1,1,1-trichloroethane, and ethanol on fixed-interval responding in mice. Neurobehav Toxicol Teratol 8:525-531

Moser VC, Scimeca JA, Balster RL (1985) Minimal tolerance to the effects of 1,1,1-trichloroethane on fixed-ratio responding in mice. Neurotoxicology 6:35-42

Nishikawa K, Harrison NL (2003) The actions of sevoflurane and desflurane on the gamma-aminobutyric acid receptor type A: effects of TM2 mutations in the alpha and beta subunits. Anesthesiology 99:678-684

Ogata J, Shiraishi M, Namba T, Smothers CT, Woodward JJ, Harris RA (2006) Effects of anesthetics on mutant $N$-methyl-D-aspartate receptors expressed in Xenopus oocytes. J Pharmacol Exp Ther 318:434-443

Ramsey J, Anderson HR, Bloor K, Flanagan RJ (1989) An introduction to the practice, prevalence and chemical toxicology of volatile substance abuse. Hum Toxicol 8:261-269

Rees DC, Coggeshall E, Balster RL (1985) Inhaled toluene produces pentobarbital-like discriminative stimulus effects in mice. Life Sci 37:1319-1325

Rees DC, Knisely JS, Balster RL, Jordan S, Breen TJ (1987a) Pentobarbital-like discriminative stimulus properties of halo- 
thane, 1,1,1-trichloroethane, isoamyl nitrite, flurothyl and oxazepam in mice. J Pharmacol Exp Ther 241:507-515

Rees DC, Knisely JS, Breen TJ, Balster RL (1987b) Toluene, halothane, 1,1,1-trichloroethane and oxazepam produce ethanollike discriminative stimulus effects in mice. J Pharmacol Exp Ther 243:931-937

Rees DC, Knisely JS, Jordan S, Balster RL (1987c) Discriminative stimulus properties of toluene in the mouse. Toxicol Appl Pharmacol 88:97-104

Riegel AC, French ED (2002) Abused inhalants and central reward pathways: electrophysiological and behavioral studies in the rat. Ann N Y Acad Sci 965:281-291

Salvini M, Binaschi S, Riva M (1971) Evaluation of the psychophysiological functions in humans exposed to the 'Threshold Limit Value' of 1,1,1-trichloroethane. Br J Ind Med 28:286-292

Shelton KL (2007) Inhaled toluene vapor as a discriminative stimulus. Behav Pharmacol 18:219-229

Shelton KL, Balster RL (2004) Effects of abused inhalants and GABA-positive modulators in dizocilpine discriminating inbred mice. Pharmacol Biochem Behav 79:219-228

Shelton KL, Dukat M, Allan AM (2004) Effect of 5-HT3 receptor over-expression on the discriminative stimulus effects of ethanol. Alcohol Clin Exp Res 28:1161-1171

Tallarida RJ, Murray RB (1986) Manual of pharmacological calculations with computer programs, 2nd edn. Springer, New York

Torkelson TR, Rowe VK (1981) Halogenated aliphatic hydrocarbons. In: Clayton GD, Clayton FE (eds) Patty's industrial hygiene and toxicology. Wiley, New York, pp 3502-3510
Troutman WG (1988) Additional deaths associated with the intentional inhalation of typewriter correction fluid. Vet Hum Toxicol 30:130-132

Warren DA, Bowen SE, Jennings WB, Dallas CE, Balster RL (2000) Biphasic effects of 1,1,1-trichloroethane on the locomotor activity of mice: relationship to blood and brain solvent concentrations. Toxicol Sci 56:365-373

Wiley JL, Fagalde RE, Buhler KG, LaVecchia KL, Balster RL (2002) Evaluation of 1,1,1-trichloroethane and flurothyl locomotor effects following diazepam treatment in mice. Pharmacol Biochem Behav 71:163-169

Winek CL, Wahba WW, Huston R, Rozin L (1997) Fatal inhalation of 1,1,1-trichloroethane. Forensic Sci Int 87:161-165

York JL (1978) A comparison of the discriminative stimulus effects of ethanol, barbital, and phenobarbital in rats. Psychopharmacology (Berl) 60:19-23

Young JM, Friedman C, Williams EM, Ross JA, Tonnes-Priddy L, Trask BJ (2002) Different evolutionary processes shaped the mouse and human olfactory receptor gene families. Hum Mol Genet 11:535-546

Zacny JP, Sparacino G, Hoffmann P, Martin R, Lichtor JL (1994) The subjective, behavioral and cognitive effects of subanesthetic concentrations of isoflurane and nitrous oxide in healthy volunteers. Psychopharmacology (Berl) 114:409-416

Zacny JP, Janiszewski D, Sadeghi P, Black ML (1999) Reinforcing, subjective, and psychomotor effects of sevoflurane and nitrous oxide in moderate-drinking healthy volunteers. Addiction 94:1817-1828 